\title{
IDENTITAS DEMOKRASI DI TANAH MANDAR: PENELUSURAN ATAS SISTEM PEMERINTAHAN DAN SOSIAL DI KERAJAAN BALANIPA
}

\section{DEMOCRACY IDENTITY IN TANAH MANDAR: SEARCHING FOR GOVERNMENT AND SOCIAL SYSTEMS IN THE KINGDOM OF BALANIPA}

\author{
Muhammad Tanzil Aziz Rahimallah ${ }^{1}$ \\ Aco Nata Saputra ${ }^{2}$ \\ Andi Nur Fiqhi Utami ${ }^{3}$
}

\begin{abstract}
Abstrak
Di Indonesia khususnya pasca reformasi, konsep-konsep demokratisasi selera lokal juga bermunculan satu-persatu, terlebih memang bahwa Indonesia sebagai salah satu negara dengan tingkat heterogenitas budaya yang sangat tinggi, terkhusus banyaknya kerajaan-kerajaan masa lampau yang pernah tumbuh dan berkembang di Indonesia menjadikan sangat banyak ditemukan nilai-nilai demokratisasi yang justru menjadi salah satu fenomena yang unik.
\end{abstract}

Kata kunsi: Demokrasi, Identitas, Tanah Mandar

\section{Pendahuluan}

Jika ada kata yang paling diagungkan oleh manusia dalam satu abad terakhir ini, kata tersebut adalah demokrasi. Demokrasi sebagai sebuah sistem kekuasaan secara konsep menempatkan kedudukan rakyat secara total sebagai pemegang kedaulatan tertinggi dalam sebuah organisasi dalam hal ini negara. Dengan rakyat sebagai kekuatan utama dalam siklus kekuasaan maka ada jaminan terhadap pengakuan dan pemenuhan terhadap hak-hak dasar rakyat itu sendiri. Hal inilah yang membuat demokrasi sebagai sebuah sistem bergaung begitu kuat sehingga dianggap sebagai sebuah solusi atas keterpurukan yang telah lama dialami oleh masyarakat.

Dalam perkembangannya hampir sebagian besar negara-negara di dunia mendadak melabeli negaranya masing-masing dengan slogan demokrasi, puluhan trilyun anggaran negara dihabiskan guna mengimplementasikan konsep demokrasi dalam sistem ketatanegaraan. Setiap negara bahkan berlomba-lomba menjadi negara yang mendapatkan predikat negara paling demokratis. Hal yang unik dari bergemanya demokrasi ini adalah cerita tentang keragaman demokrasi yang dimiliki oleh setiap negara di dunia dengan ciri khasnya sendiri-sendiri.

Di Indonesia khususnya pasca reformasi, konsep-konsep demokratisasi selera lokal juga bermunculan satu-persatu, terlebih memang bahwa Indonesia sebagai salah satu negara dengan tingkat heterogenitas budaya yang sangat tinggi, terkhusus banyaknya kerajaan-kerajaan masa lampau yang pernah tumbuh dan berkembang di Indonesia menjadikan sangat banyak ditemukan nilai-nilai demokratisasi yang justru menjadi salah satu fenomena yang unik.

Halim (2016: 4) menyatakan banyak penelitian dan kajian yang dilakukan oleh para ilmuan yang bertujuan untuk menggali, menemukan kembali, serta menyandingkan konsep demokrasi

\footnotetext{
${ }^{1}$ Dosen Program Studi Politik Konsentrasi Ilmu Pemerintahan, Fakultas Ilmu Sosial dan Ilmu Politik - Universitas Sulawesi Barat, e-mail: mtazilar@unsulbar.ac.id

2 Dosen Program Studi Politik Konsentrasi Ilmu Administrasi Publik, Fakultas Ilmu Sosial dan Ilmu Politik Universitas Sulawesi Barat e-mail: puanglembang23@gmail.com

${ }^{3}$ Dosen Program Studi Politik Konsentrasi Ilmu Pemerintahan, Fakultas Ilmu Sosial dan Ilmu Politik - Universitas Sulawesi Barat, e-mail: anurfiqhiu@unsulbar.ac.id
} 
lokal yang pernah atau bahkan masih ada di Indonesia dengan konsep demokrasi modern. Sebagian besar dari penelitian tersebut membuat kita sadar bahwa konsep demokrasi yang kita agung-agungkan sebenarnya telah lama ada ditengah-tengah masyarakat kita, bahwa demokrasi itu tidaklah identik dengan orang-orang barat saja, tapi juga para nenek moyang kita orang Indonesia ternyata telah menemukan dan mempraktekkan secara langsung tentang konsep demokrasi lengkap dengan ciri khas adat-istiadat dan kebudayaannya masing-masing.

Serupa dengan dimunculkannya kembali konsep-konsep demokrasi dalam bingkai kearifan lokal dari berbagai daerah di nusantara, di tanah Mandar Sulawesi Barat tepatnya di sekitaran daerah Kabupaten Polewali Mandar dan Kabupaten Majene pada kisaran abad ke XVI pernah ada salah satu kerajaan yang memiliki tingkat peradaban yang realtif maju pada saat itu yakni kerajaan Balanipa. Hal yang menarik dari keberadaan kerajaan Balanipa adalah pengembangan sistem pemerintahannya sangat banyak memunculkan model yang sesuai dengan prinsip-prinsip demokrasi. Penelitian ini coba untuk memberikan gambaran bahwa pada dasarnya penerapan nilai-nilai demokrasi juga telah jauh di diterapkan oleh orang-orang Mandar (Sulawesi Barat) khususnya dalam sistem pemerintahan dan juga sistem sosial yakni di Kerajaan Balanipa.

\section{Metode Penelitian}

Jenis penelitian ini adalah penelitian kualitatif, menurut Bungin (2001:49), masalah dalam penelitian kualitatif berwilayah pada ruang yang sempit, dengan tingkat variasi yang rendah, namun memiliki kedalaman bahasan yang tidak terbatas. Sementara itu, masalah dalam penelitian kuantitatif biasanya bersifat umum, memiliki wilayah yang luas dan tingkat variasi yang kompleks, namun berlokasi di permukaan.

Menelusuri perkembangan demokratisasi orang Mandar khususnya internal kerajaan Balanipa maka mau tidak mau kita harus menggunakan perspektif sejarah untuk mengupasnya sehingga pendekatan yang digunakan adalah antropologis-historis dengan tujuan untuk mengkaji sumber-sumber sejarah kerajaan Balanipa untuk menemukan dan mengidentifikasi nilai-nilai demokrasi dalam sistem pemerintahan kerajaan Balanipa termasuk juga sistem sosial yang berlaku dimasyarakat sejak abad ke-16 hingga abad ke-20.

Data dikumpulkan dengan cara telaah pustaka tentang sejarah kerajaan Balanipa, baik yang berasal dari catatan pribadi, buku-buku karangan tokoh adat lokal, baik yang sudah diterbitkan maupun yang masih berupa draft; dan wawancara mendalam terhadap para tokoh-tokoh masyarakat dan pemerhati budaya. Setelah data terkumpul maka perlu diadakan verifikasi data dan kritik untuk memperoleh keabsahan data yang telah diperoleh khususnya menggunakan kritik sumber. Abdurrahman (1999: 58-59) Dalam melakukan sebuah kritik sumber ada dua hal yang perlu diperhatikan, yang pertama kritik eksternal (otentisitas).Dalam hal ini berkaitan dengan kritik tentang keabsahan keaslian sumber.Kedua kritik internal (kredibilitas) dalam hal ini berkaitan dengan kritikan keabsahan tentang kebenaran sumber.

Analisis data dilakukan dengan mengklasifikasi dan memilah data-data, menentukan pola hubungan antara data satu dengan lainnya, dan melakukan penafsiran atas data-data tersebut untuk mendapatkan kesimpulan yang valid tentang nilai-nilai demokratisasi dalam sistem pemerintahan dan sistem sosial masyarakat yang bernaung dalam wilayah kekuasaan kerajaan Balanipa.

\section{Pembahasan \\ Nilai-nilai demokrasi dalam berbagai perspektif}


J.J. Rousseau (2007: 113) dalam buku Du Contract Social (Perjanjian Sosial) mendefinisikan bahwa demokrasi sebagai sebuah proses yang mutlak dilalui oleh sebuah negara dalam upayanyan untuk mendapatkan kesejahteraan. Kendati demikian Rousseau pada dasarnya menyadari bahwa demokrasi diposisikan sebagai senuah proses transisi menuju perkembangan sisitem ketatanegaraan yang sempurna. Demokrasi akan berjalan sesuai dengan perkembangan waktu dan faktor budaya sebuah negara akan mendapatkan peranan yang sangat besar dalam membentuk ciri khas demokratisasi sebuah negara.

Demokrasi sebagai sistem pemerintahan dari dan untuk rakyat atau bisa dimaknai sebagai pemerintahan dengan dukungan rakyat; pemerintahan dimana kekuasaan tertinggi terletak pada rakyat dan dikendalikan secara langsung oleh rakyat atau oleh perwakilan-perwakilan yang telah mereka pilih melalui sebuah sistem pemilihan yang terbuka.

Roger Trigg (2007: 130) mengungkapkan sebuah negara demokrasi adalah negara dimana pemerintah bertanggungjawab kepada rakyat, dan bisa dijatuhkan oleh rakyat dalam proses pemilihan umum. Walaupun rakyat telah memberikan kekuasaannya kepada pemerintah, namun mereka (rakyat) masih tetap memegang kekuasan tertinggi. Syarat daripada pelaksanaan demokrasi adalah kebebasan individu berasaskan pada kesadaran bahawa semua rakyat adalah bebas untuk menentukan keputusan tentang apa yang penting, rakyat sebagai penentu segala sesuatu sehingga memiliki kekuatan untuk mengawal pemerintahan ${ }^{4}$

Hans Kelsen dalam Thalhah (2009:413-422) mengungkapkan bahwa demokrasi terbentuk diawali dari proses kompromi yang sehat antara kelompok mayoritas dengan minoritas, kondisi ini tidak hanya terjadi dalam parlemen atau pemerintahan saja, tapi juga melembaga dalam kehidupan politik yang lain. Selanjutnya prinsip demokrasi menurut Hans Kelsen adalah:

1. Adanya kehendak mayoritas dan kehendak minoritas

2. Kehendak mayoritas tidak bisa menjadi dominasi absolut

3. Adanya kompromi di antara kehendak mayoritas dengan kehendak minoritas dalam menyikapi sebuah permasalahan dan dalam pembentukan sebuah tatatan.

4. Tidak ada pemaksaan dalam beragama dan berkeyakinan

5. Terdapat kebebasan berbicara, kebebasan pers, dan pendapat untuk mengemukakan pendapat dijamin keberadaannya, baik melalui konstitusi ataupun melalui kesepakatan adat yang terjadi di sebuah negara.

6. Kompromi yang sehat menjadikan tidak diketemukannya benturan kepentingan antara kehendak mayoritas dan kehendak minoritas yang biasanya akan berbuah pada tindakan anarki.

Penerapan demokrasi minimal mencakup unsur-unsur berikut ini: (1) kedaulatan rakyat; (2) pemerintahan berdasarkan persetujuan dari yang diperintah; (3) kekuasaan mayoritas; (4) hak-hak minoritas; (5) jaminan atas hak-hak asasi manusia; (6) pemilihan yang bebas dan jujur; (7) proses hukum yang wajar; (8) pembatasan kekuasaan pemerintah secara konstitusional; (9) pluralisme sosial, ekonomi, dan politik sebagai elemen-elemen masyarakat sipil (CCE, 2007). Selain itu, diperlukan pula adanya penghormatan terhadap nilai-nilai toleransi, pragmatisme, kerja sama, dan mufakat.

Seperti diringkaskan oleh Friedman (1992: 75), demokrasi menyiratkan makna bahwa orang-orang yang diatur dalam komunitas politik adalah sumber tertinggi dari kekuasaan yang berdaulat atas ruang hidup mereka, yang persisnya, dalam era modern, membentuk wilayahwilayah yang terikat. Sebagai "organ pemerintahan" dari masyarakat politik tersebut, negara 
berdaulat atas wilayahnya hanya berkat perluasan kedaulatan orang-orang yang tinggal di dalamnya. Untuk seluruh tindakannya, negara bertanggung jawab kepada masyarakatnya).

Beberapa konsep dan pendekatan tentang demokrasi yang diuraikan tersebut pada dasarnya memberikan kesimpulan teori tentang demokrasi yang bisa dijadikan acuan dalam menelusuri dan memetakan nilai-nilai demokrasi yang juga dipraktekkan oleh masyarakat Mandar khusunya dalam wilayah kekuaksaan kerajaan Balanipa.

\section{Mandar: Peradaban di Hulu dan Hilir sungai}

Orang Mandar adalah penamaan yang diberikan oleh orang-orang dari Kerajaan Luwu, Bone dan Gowa sebagai kerajaan besar yang ada di daerah Sulawesi pada orang-orang yang bermukim di daerah sungai Mandar (Sungai Tinambung). Awal pemberian penamaan Mandar ini sangat identik dengan dengan teritorial kehidupan orang-orang Mandar yang hidup disekitar sungai Mandar termasuk mereka yang menggantungkan kehidupannya pada sungai Mandar. Akan tetapi dalam perkembangan penamaan Mandar ini oleh kalangan orang Mandar sendiri bisa didefinisikan kuang lebih dari dua pendekatan baik secara terminologis maupun etimologis.

Muhamad Munir tokoh masyarakat dan budayawan Mandar menjelaskan secara terminologis atau secara bahasa, Mandar berarti sungai yang deras arusnya. Muhammad Ilyas dalam pengartian lain memahami bahwa kata Mandar identik dengan makna ma andar (mengantar) karena fungsi sunga Mandar pada zaman dulu dijadikan sebagai media pengiriman barang dari daerah gunung/hulu ke daerah pantai/hilir. Sedangkan secara etimologis atau istilah, Mandar berarti bersifat seperti air atau secara lebih mendalam Mandar diartikan bersifat seperti air yang mencari kemuliaan pada titik terendah. (Munir dan Ilyas. Personal Communication. 2019. 14 September)

Pendefinisian ini yang kemudian berkembang dan memberikan pemaknaan yang lebih luas pada kata Mandar. Muhlis Hannan menjelaskan, kurang lebih ada 4 aspek pendefinisian Mandar yakni secara teritorial merujuk pada posisi geografis sungai Mandar dan sekitarnya, secara sosiologis merujuk pada orang-orang yang hidup disekitar sungai Mandar dengan kebiasaan dan adat istiadanya, secara linguistik merujuk pada bahasa yang diuganakan oleh orang-orang Mandar, dan secara filosofis merujuk pada sifat-sifat orang Mandar yang kuat memegang prinsip sebagai ciri khasnya (amandarang). (Hannan, Muhlis. Personal Communication. 2019. 20 September)

Sejarah perkembangan peradaban orang-orang Mandar diawali dari keberadaan kelompokkelompok kecil manusia yang biasanya terikat dalam ikatatan darah sehingga membentuk rumpun keluarga besar dan hidup secara mandiri dalam bentuk perkampungan. Setiap anggota kelompok ini sejak awal telah memiliki kemerdekaan dan kebebasan dalam melaksanakan kehidupan sehari-hari walaupun mereka tetap terikat dengan aturan-aturan dan kebiasaan khususnya dalam hubungan sosial. Kelompok-kelompok kecil ini dipimpin atau dikepalai oleh seorang kepala kampung (Tomakaka).

Tomakaka biasanya merupakan perwakilan masyarakat yang bernaung dalam perkampungan yang ditentukan berdasarkan kecakapan, kesaktian dan karakter kepemimpinan atau bisa juga adalah orang yang dituakan. Penting untuk diketahui bahwa Tomakaka merupakan representasi kekuasaan dari setiap perkampungan yang keberadaannya diakui dan diterima oleh setiap anggota kelompoknya. Proses pembauran dan bergabungnya kelompok-kelompok kecil ini kemudian memunculkan kerajaan-kerajaan dengan skala kecil namun jumlahnya cukup banyak, tercatat sebanyak 41 perkampungan dengan tomakaka-nya masing-masing (Leyds, 2006: 19-20) 
Di sekitar abad ke 13, sebagai periode awal kerjaan yang ada di Mandar telah dikenal kerajaan yang mula-mula mendiami wilayah Mandar yakni kerajan Pasokkorang, Kerajaan Pasokkorang dalam catatan sejarah seumur dengan Kerjaaan Bangkala dan Kerajaan Binamu (daerah Jeneponto saat ini). Kerjaaan Pasokkorang diketahui sebagai kerajaan yang memiliki kekuasaan terbesar yang berada di wilayah Mandar dengan kekuatan militer yang tangguh dan menguasai wilayah Mandar kurang lebih selama tiga abad.

Di pertengahan abad 15, mulai muncul pemberontakan terhadap kerajaan Pasokkorang dikarenakan semakin beringas dan sewenang-wenangnya kerajaan pasokkorang terhadap rakyatnya khususnya pada masa kepemimpinan dua raja terakhir yakni Takia Bassi dan La Bassi Kalling. Dalam perspektif lain ditemukan juga disebutkan bahwa kecenderungan kerajaaan pasokkorang ingin menyerang dan menguasai daerah-daerah kawasan pesisir barat Sulawesi karena secara ekonomi pasokkorang ingin mengembangkan perekonomian kerajaannya dengan membuka jalur-jalur perdagangan melalui laut. (Munir, Muhammad. Personal Communication. 2019. 10 September)

Keberadaan kampung-kampung di wilayah hilir sungai Mandar atau kawasan pesisir yang peradabannya semakin berkembang dianggap sebagai ancaman, sehingga untuk memuluskan ekspansi jalur perdagangan kerajaan pasokkorang maka kampung-kampung tersebut perlu ditaklukkan terlebih dahulu. (Ridwan, Muhammad. Personal Communication. 2019. 24 September)

Muhammad Amir (2014: 27) dalam bukunya Gerakan Mara'dia Tokape di Mandar 18701873 juga menyebutkan bahwa latar belakang lahirnya persekutan Appe Banua Kayyang memang untuk mengindari penjajahan dari pihak luar bukan hanya dari kerajaan Pasokkorang tapi juga dari Tomakaka Lenggo, Tomakaka Lempong dan Tomakaka Tande.

Saat mengetahui keinginan kerajaan Pasokkorang utuk memperluas wilayah kekuasaannya dan menaklukkan wilayah hilir sungai Mandar, maka kelompok-kelompok perkampungan besar yang selanjutnya disebut Appe Banua Kayyang (empat perkampungan besar) yang ada di sekitar wilayah hilir sungai Mandar mulai melakukan persiapan dan perlawanan terhadap kerajaan Pasokkorang. Perkampungan tersebut adalah perkampungan yang berada wilayah Napo, Mosso, Todang-Todang dan Samasundu. Pemimpin dari Appe Banua Kayyang yang mendiami wilayahwi;ayah tersebut kemudian di sebut Tomakaka Napo, Tomakaka Mosso, Tomakaka TodangTodang dan Tomakaka Samasundu. Nama Tomakaka dari Appe Banua Kayyang ini pasca terbentuknya kerajaan Balanipa berubah menjadi Pappuangan.

Pemimpin Appe Banua Kayyang yakni Pappuangan Napo, Pappuangan Mosso, Pappuangan Todang - Todang dan Papuanngang Samasundu, pada dasarnya menyadari bahwa kekuatan mereka tidak akan mampu menandingi kekuatan militer kerajaan Pasokkorang. Kondisi ini membuat Appe Banua Kayyang (empat perkampungan besar) tersebut bersekutu dan kemudian bersepakat untuk meminta bantuan dan pertolongan dari kerajaan Gowa dan secara khusus pada sosok I Manyambungi yang setelah wafat digelari To Dilaling (Amir, 2011: 50)

\section{Kerajaan Balanipa: Kompromi Appe Banua Kayyang dan I Manyambungi}

I Manyambungi merupakan keturunan orang Mandar yang menjadi pangilma perang Kerajaan Gowa pada saat Raja Gowa IX Karaeng Tumaparisik Kallonna bertahta sekitar awal abad ke 15. I Manyambungi menjadi panglima perang handal bagi kerajaan Gowa dan mampu menaklukan banyak daerah sehingga menjadi wilayah kekuasan kerajaan Gowa menjadi semakin besar. Wilayah yang ditaklukkan I Manyambungi seperti Tambora (Nusa Tenggara Timur) dan Pariaman. Kebesaran nama I Manyambungi karena kedudukannya sebagai orang penting kerjaan 
Gowa dan keturunan darah Mandar yang dimilikinya inilah yang membuat Appe Banua Kayyang (empat perkampungan besar) Pappuangan Napo, Pappuangan Mosso, Pappuangan TodangTodang dan Papuanngang Samasundu sangat berharap bantuan dari I Manyambungi.

Persekutuan Appe Banua Kayyang mengutus Puang Dipoyosang, orang yang berasal dari wilayah Limboro (Pappuangan Limboro) yang masih memiiki hubungan darah dengan I Mayambungi untuk meminta dan membujuk I Mayambungi agar mau kembali ke Mandar dan membantu mereka mengahdapi keganasan kerajaan Pasokkorang. Setelah I Manyambungi yang dibantu oleh kerajaan Gowa berhasil mengalahkan kerajaan Pasokkorang maka Appe Banua Kayyang merasa bahwa penting kiranya mebuat persekutuan yang lebih besar (federasi) yang terdiri dari wilayah Napo, Mosso, Todang-Todang dan Samasundu dengan harapan bahwa keempat wilayah tersebut akan saling membantu dan menjaga terlebih pada saat terjadi penyerangan dari kerjaan lain. Persekutuan ini juga diharapkan mambu memberikan ketentraman dan kesejahteraan bagi rakyat yang berada diwilayah Appe Banua Kayyang karena sampai pada saat itu budaya dan peradaban masyarakat di Appe Banua Kayyang masih cenderug bar-bar dan memberlakukan hukum rimba. Kesadaran inilah yang membuat Appe Banua Kayyang bersepakat untuk membentuk Kerajaan yang selanjutnya dikenal dengan sebutan kerjaaan Balanipa. (Saharuddin, 1985: 45; Kila, 2014: 213).

Kecakapan dan kecerdasan I Manyambungi menjadi pertimbangan besar dari Appe Banua Kayyang untuk mengangkat I Manyambungi sebagai raja pertama Kerajaan Balanipa. Proses pengangkatan raja Balanipa pertama ini sudah memberikan gambaran demokratisasi orang-orang Mandar khususnya yang tergabung dalam persekutuan Appe Banua Kayyang.

Dalam proses pelantikan raja pertama Balanipa ini ada bentuk perjanjian yang dilakukan oleh Pappuangan Limboro sebagai perwakilan dari Appe Banua Kayyang dengan I Manyambungi yang dikenal dengan istilah Assitaliang/pertalian. Dalam perjanjian itu Pappuangan Limboro dan I Manyambungi bersepakat bahwa Pengangkatan I Manyambungi sebagai raja adalah bentuk penyerahan kedaulatan kekuasaan dari rakyat Appe Banua Kayyang.

Pappuangan Limboro sebagai ketua dewan adat yang mewakili Appe Banua Kaiyang dan atas nama rakyat mengambil sumpah calon raja yang berbunyi:“Upakaiyangngo'o, mupakaraja', madondong duang bongi anna marrattoso'o wake', maruppu-ruppu'o batu, uwalai membali akaiyangan". Artinya, kami angkat engkau menjadi pemegang tampuk pemerintahan, tetapi engkau harus menghormati kami, besok lusa manakala engkau memutuskan sendi-sendi adat dan menghancurkan aturan dan kebiasaan adat negeri, maka kami akan mengambil kembali kebesaran yang telah kuberikan. (Saharuddin. 1985: 31)

Secara langsung Assitaliang mengokohkan bahwa kedaulatan tertinggi dari Kerajaan Balanipa berasal dari rakyat dan untuk rakyat dengan raja Balanipa sebagai pelaksana kedaulatan tersebut. Inilah yang menjadi dasar dan dianggap sebagai perwujudan demokratisasi yang ada di kerajaan Balanipa.

\section{Appe Banua Kayyang dan Keterwakilan rakyat}

Appe Banua Kayyang jika dilihat dari struktur kepengurusannya maka secara modern hampir sama dengan model presidium. Appe Banua Kayyang yang terdiri dari pappuanagan Napo, Pappuangan Samasundu, Pappuangan Mosso dan Pappuangan Todang-todang memiliki kedudukan hampir sama walaupun secara tidak tertulis Napo selalu mendapatkan kehormatan sebagai yang dituakan atau yang diikuti. Masing-masing Pappuangan mempunyai kekuasaan mengatur dan mengurus daerahnya sesuai dengan kepercayaan yang diberikan rakyat kepada mereka. Selain sebagai pemimpin daerah papuangan juga menjadi anggota dari lembaga adat 
yang dikenal dengan dewan ada' kaiyyang (adat besar). Dewan ada' kaiyyang yang kemudian berhak memilih dan mengangkat serta memberhentikan seorang raja atau mara'dia pada Kerajaan Balanipa. (Polinggomang. 2012: 33)

Berdasarkan pemaparan di atas dapat disimpulkan bahwa Kerajaan Balanipa Pemimpin dari Appe Banua Kayyang pada dasarnya merupakan representasi masyarakat yang dipilih secara mufakat oleh para Tomakaka atau kepala kampung kecil yang ada di masing-masing wilayah dari Appe Banua Kayyang. Selanjutnya dari hasil kesepaktan Appe Banua Kayyang tentang siapa yang berhak dan pantas menjadi raja didelegasikan kepada Pappuangan Limboro sebagai representasi masyarakat dari Appe Banua Kayyang untuk melantik Raja Balanipa.

Hal ini juga memperkuat kedudukan Appe Banua Kayyang, tidak hanya sebagai pemegang kekuasaan adat, akan tetapi Appe Banua Kayyang juga menjadi representasi/keterwakilan kedaulatan rakyat dalam sistem kekuasaan.

\section{Persamaan hak/kedudukan laki-laki dan perempuan}

Laki-laki dan perempuan dalam budaya Mandar berdasarkan perspektif kekuasaan dan kedudukan dianggap setara. Hal ini dapat dilihat dari peran dan keterlibatan kaum perempuan dalam kehidupan sehari-hari mulai dari lingkup keluarga sampai pada lingkup sosial yang lebih besar. dalam lingkup keluarga, laik-laki dan perempuan memiliki kedudukan yang sama khususnya dalam urusan pemenuhan kebutuhan sehari-hari.

Sahabuddin (2013: 61) mengungkapkan adanya nilai budaya sibaliparriq (sependeritaan) yang melekat pada masyarakat Mandar menyebabkan kaum perempuan dituntut mengambil peran ganda yang tidak hanya mengurusi urusan rumah tangga namun juga harus mampu menafkahi keluarganya terlebih saat suaminya pergi melaut. Hal ini menyebabkan kedudukan perempuan yang setara dengan kaum pria sejak dalam lingkup keluarga telah ditanamkan dan terbawa pula sampai pada lingkup sosial yang lebih luas.

Rahman (2015: 85-86) mengungkapkan bahwa kedudukan laki-laki dan perempuan dalam budaya Mandar itu setara. Hal ini terbukti dalam proses penghitungan nilai darah (kadar kebangsawanan) seseorang yaitu dengan menjumlahkan nilai kadar darah bapak dengan nilai kadar darah ibu dan kemudian dibagi dua. Hasilnya yang kemudian dijadikan patokan untuk menentukan niai kadar darah anak keturunannya.

Kondisi yang paling membuktikan persamaan kedudukan laki-laki dan perempuan dalam budaya orang Balanipa bisa dilihat dari kedudukan perempuan dalam sistem pemerintahan kerajaan Balanipa. Dalam catatan sejarah kepemimpinan kerjanaan Balanipa juga memunculkan tokoh-tokoh perempuan sebagai raja. Tercatat ada dua orang perempuan yang mampu menjadi pemimpin kerajaan Balanipa (arajang) yakni Hj. Andi Depu (Sugiranna Andi Mania) raja Balanipa ke-50 yang memerintah pada tahun 1947 sampai 1953 dan Puang Mondaq (Hj. Syahribulang Batara Tungka) sebagai raja Balanipa ke-51 yang memerintah pada 1959-1963.

\section{Ketiadaan bangunan kerajaan dan juga upeti terhadap raja}

Bangunan kerajaan biasanya selain menjadi simbol keberadaan kerajaan, juga sebagai tempat tinggal raja sekaligus sebagai pusat pemerintahan tempat dilakukannya kegiatan-kegiatan penting seperti perumusan dan pengambilan kebijakan kerajaan, menerima tamu dan juga pertemuan-pertemuan penting lainnya. Umumnya bangunan kerajaan dibangun di posisi yang strategis dengan desain semegah mungkin karena menjadi representasi kemakmuran sebuah kerajaan sehingga bangunan kerajaan identik dengan sebutan istana kerajaan. 
Dalam sejarah kerajaan Balanipa, mulai dari raja pertama menjabat sampai pada raja terkahir tidak ditemukan keberadaan istana kerajaan yang dibangun secara khusus sebagai simbol kerajaan. Hal ini disebabkan karena istana kerajaan Balanipa secara langsung adalah rumah tempat tinggal dari raja. Siapapun yang terpilih menjadi raja, maka rumah tempat tinggalnya secara otomatis menjadi istana kerajaan. (Ilyas, Personal Communication. 2019. 29 September)

Kondisi ini memberikan makna bahwa pada dasarnya raja adalah bagian dari masyarakat Balanipa, tidak ada sekat-sekat yang membatasi antara raja dengan rakyatnya. Kedekatan antara pemimpin dengan rakyat yang dipimpin tidak ada dalam batasan bangunan megah yang membuat siapa saja dari kalangan rakyat akan dengan mudah bertemu dengan raja baik itu untuk meminta pendapat, memberi masukan ataupun mengadukan sebuah kondisi kepada pemimpin kerajaan.

Hal lain yang juga tergolong unik dan tidak biasa dalam sistem pemerintahan kerajaan Mandar adalah tidak adanya penarikan pajak atau upeti dari raja kepada rakyat. Raja dalam pemenuhan kebutuhan sehari-harinya tetap harus mengusahakan sendiri kebutuhannya baik itu dengan berkebun ataupun menangkap ikan. Kalaupun raja mendapatkan tanah biasanya hanya sebagai pemberian ataupun hadiah dari para tau pia sebagai pemilik wilayah. Hal ini pula yang membuat kemungkinan tidak adanya aset-aset kerajaan seperti istana karena memang tidak ada pajak/upeti yang diambil pemerintah kerajaan dari rakyat. Begitu juga untuk membiayai urusanurusan operasional kerajaan maka anggaran yang digunakan biasanya murni dari swadaya para tau pia dan masyarakat.

\section{Tahta raja yang tidak turun-temurun}

Bentuk demokratisasi yang paling nampak dari kebudayaan orang-orang Balanipa adalah sistem pemerintahan kerajaan Balanipa yang tidak mewariskan tahta raja secara turun temurun. Proses pemilihan raja dilaksanakan dengan cara dipilih dan disetujui oleh Appe Banua Kayyang yang merupakan representasi dari kedaulatan rakyat.

Setiap orang Mandar yang memiliki kemampuan, prestasi dan etika yang baik dan mumpuni pada dasarnya memiliki hak untuk menjadi raja Balanipa. I Manyambungi sebagai tokoh besar kerajaan Balanipa sekaligus sebagai raja pertama menegaskan hal ini sebelum beliau mangkat. I Manyambungi secara tegas memberikan arahan bahwa setelah dia wafat, bahkan anak cucunya sekalipun jika tidak memiliki kemampuan dan etika yang baik maka jangan pilih dia menjadi raja/maraqdia. Secara lengkap amanah itu berbunyi, bahwa "Madondong duambongi anna matea, mau ana'u mau appo'u da' muannai menjari mara'dia mua tania tonamassayanni lita 'na to massayanni pa'banua. Da' muannai dai di peuluan, mua masuanni pulu-pulunna, mua maddori kedona, apa iyamo ta'u namarruppu-ruppu lita'. Artinya manakala besok lusa saya mangkat, walaupun anak dan cucu saya, janganlah hendaknya diangkat menjadi raja kalau bukan dia orang yang cinta kepada tanah air dan rakyat kecil. Jangan pula diangkat seorang calon raja bila ia mempunyai tutur kata yang kasar, berbuat, bertindak kaku dan kasar pula, karena orang yang seperti itulah yang akan meng-hancurkan negeri” (Saharuddin, 1977: 20-21).

Dalam sejarah kepemimpinan kerajaan Balanipa, keterbukaan dalam menduduki jabatan raja Balanipa menyebabkan sistem pengawan dan kontrol terhadap baik sebelum dilantik maupun setelah dilantik juga sangat ketat. Jika Appe Banua Kayyang sebagai representase rakyat menganggap bahwa raja yang memerintah melakukan pelanggaran dan kesalahan maka proses pemakzulan terhadap raja dapat dilakukan. 
Muhammad Munir mengatakan bahwa jika kepemimpinan raja banyak terjadi pelanggaran dan penyelewengan maka Appa Вапиа Kayyang akan meminta bertemu dengan raja, Appe Banua Kayyang dalam kondisi seperti ini akan mengikatkan passapu (pengikat kepala) yang dimiringkan/dibengkokkan atau digunakan dengan posisi yang tidak biasa. Hal ini sebagai simbol keinginan agar raja mengundurkan diri dari tahtanya, bahkan jika tidak mengundurkan diri maka raja bisa saja dibunuh atau dihakimi secara langsung oleh rakyatnya sendiri. Hal ini pernah terjadi pada masa kepemimpinan Raja Daeng Rioso raja Balanipa XII. (Munir, Muhammad. Personal Communication. 2019. 20 September)

\section{Kelembagaan dan sistem pemerintahan (Pemisahan Kekuasaan)}

Sistem pemerintahan kerajaan Mandar jika merujuk pada konsep trias politica (pemisahan kekuasaan dalam tiga aspek) yang dipopulerkan oleh montesque tahun 1748 dikatakan bahwa dalam tiap pemerintahan negara harus ada 3 (tiga) jenis kekuasaan yang tidak dapat dipegang oleh satu tangan saja, melainkan harus masing-masing kekuasaan itu terpisah. (Yulistyowati. 2016: 4)

Busroh (2010: 85) merinci pada pokoknya ajaran trias politica isinya adalah tiap pemerintahan negara harus ada 3 (tiga) jenis kekuasaan yaitu legislatif, eksekutif dan yudikatif. Kekuasaan legislatif adalah membuat undang-undang, kekuasaan eksekutif adalah kekuasaan melaksanakan undang-undang, dan kekuasaan yudikatif adalah kekuasaan mengadili atas pelanggaran undang-undang

Dalam sistem pemerintahan Balanipa juga pada dasarnya telah menerapkan sistem pemisahan kekuasan. Fungsi legilslatif dalam sistem pemerintahan kerajaan Balanipa seperti yang telah diuraikan sebelumnya bahwa keterwakilan rakyat di jalankan oleh Appe Banua Kayyang. Kedudukan Appe Banua Kayyang selain menjadi pemangku adat di pusat pemerintahan kerajaan, juga sebagai pemimpin banua/kampung artinya mereka tetap menjalankan pemerintahan atau kepemimpinan atas banua asal masing-masing, di samping jabatan mereka sebagai pemangku adat di pusat pemerintahan. (Asdy. 2003: 74)

Ada keunikan terkait kedudukan Аpрe Banua Kayyang termasuk juga anggota adat yang lain karena ditingkat kampung/banua sebagai pemimpin (eksekutif) sedangkan ditingkat pemerintahan kerajaan/pusat menjadi dewan adat sekaligus representasi/keterwakilan kedaulatan rakyat.

Fungsi eksekutif dalam sistem pemerintahan kerajaan Balanipa khususnya di pemerintah pusat dipegang oleh raja/arajang sedangkan di level yang lebih kecil dalam hal ini kampung/banua tetap dipegang oleh Pappuangan/Tomakaka. Raja/arajang selain menjadi simbol kerajaan juga menjadi kepala pemerintahan dibantu oleh beberapa Pappuangan yang bertindak sebagai menteri.

Adapun fungsi yudikatif dijalankan oleh Pabbicara Kaiyang, yang bertugas membantu maraqdia di bidang hukum, memimpin sidang-sidang, dan pendamping tetap maraqdia Balanipa (Sjam. 1990: 9). Secara struktur sebenarnya kedudukan Pabbicara Kaiyang ini ada dibawah fungsi eksekutif karena kedudukan Pabbicara Kaiyang ditunjuk oleh raja Balanipa dengan persetujuan Appe Banua Kayyang.

Dalam menjalankan fungsi yudikatifnya Pabbicara Kaiyang menempati kedudukan yudikatif dilevel pemerintah pusat, sedangkan dilevel yang lebih rendah dalam hal ini banua/kampung peran pengakan hukum dibantu oleh para tomawuweng. Keberadaan Pabbicara Kaiyang sebagai pelaksana fungsi yudikatif juga menunjukkan bagaimana penerapan dan penegakan hukum yang sangat diproritaskan dalam menjamin terciptanya keadilan dan 
ketentraman dalam kehidupan sosial orang-orang yang bernaung dalam sistem pemerintahan kerajaan Balanipa pada saat itu.

Berdasarkan pemaparan diatas sebenarnya penerapan konsep trias politica sudah diterapkan dalam sistem pemerintahan kerajaan Balanipa. Hanya saja keberadaan legislatif, eksekutif dan yudikatif tidak dipisahkan secara jelas walaupun sudah ada struktur jelas yang menjalankan fungsi-fungsi tersebut. Kedudukan lembaga yudikatif yang berada di bawah lembaga eksekutif hampir sama dengan konsep pemisahan kekuasaan yang ditawarkan oleh John Locke yang memasukkan funsi yudikatif dalam kewenangan eksekutif. Terlepas dari hal itu, untuk sistem pemerintahan lampau, gambaran tentang kedudukan lembaga-lembaga pemerintahan dalam sistem pemerintahan kerajaan Balanipa sangatlah mengagumkan. Dengan segala keterbatasan pada saat itu, kerajaan Balanipa telah mampu menciptakan dan menerapkan sistem pemerintahan yang sangat demokratis.

\section{Nilai-Nilai Demokratisasi Orang Mandar (Kerajaan Balanipa) \\ a. Angga, siri’ dan lokko nilai sosial dan budaya dasar orang Balanipa}

Dalam sistem kebudayaan orang Balanipa, ada nilai-nilai dasar yang menjadi penentu dan pedoman utama masyarakat dalam berpikir, bertutur dan bertindak. Nilai-nilai dasar ini mempengaruhi hampir keseluruhan prilaku orang-orang Mandar baik dalam secara pribadi, keluarga terlebih lagi dalam kehidupan bermasyarakat yang pada akhirnya nilai-nilai ini pula yang membentuk sistem budaya dalam pengertian luas yang tentunya membentuk peradaban orang-orang Mandar. Nilai dasar ini sangat identik dengan pengakuan terhadap kebebasan dan hak-hak mutlak yang dimiliki oleh setiap individu yang harus dihargai dan dijunjung tinggi keberadaannya.

Muhammad Ilyas menjelaskan pada dasarnya nilai-nilai sosial orang Balanipa terdiri dari tiga unsur yaitu angga, siri dan lokko walaupun secara umum hanya siri dan lokko yang lebih banyak dipahami dan dipergunakan untuk menggambarkan nilai-nilai dasar yang dijadikan pegangan orang Balanipa dalam menjalani kehidupan sehari-harinya. Angga lebih dipahami sebagai nilai-nilai utama yang berisi baik dan buruk, benar dan salah, hal yang pantas dan tabu baik itu nilai-nilai untuk diri sendiri maupun dalam lingkungan sosial yang lebih luas seperti hubugan kemasyarakatan. Dalam perkembangannya angga inilah yang kemudian menjadi substansi materi pembentuk $a d a^{\prime}$ atau hukum adat orang Balanipa. Sedangkan siri adalah kemampuan untuk melaksanakan dan mempertahankan angga. Siri inilah yang selanjutnya menjadi takaran terhadap nilai diri/harga diri seseorang. Sebaliknya, saat seseorang dianggap gagal menjaga nilai-nilai angga maka hal inilah yang disebut lokko (Ilyas, Personal Communication. 2019. 29 September)

Siri' dan lokko merupakan dua elemen rasa kemanusiaan yang muncul karena disebabkan adanya kepekaan sosial. Siri' dan lokko termanifestasikan dalam tindakan sehari-hari orang Mandar berupa perasaan malu, rendah hati, harga diri, kejujuran, solidaritas, harkat kemanusiaan,dan lain sebagainya. Siri' dan lokko menjadi pegangan teguh bagi setiap orang di Balanipa mencegah dari tindakan-tindakan negatif dan mendorong pada tindakan positif. (Rahman. 2015: 97-103)

Siri dapat dipahami sebagai pemahaman terhadap nilai-nilai kemanusiaan yang baik, sedangkan lokko lebih sebagai harga diri dalam pandangan harkat dan martabat seseorang. Ada kalanya penggunaan istilah siri' mengarah pada perspektif personal sehingga jika ada pelanggaran terhadap nilai siri' akan ditanggung secara personal pula, sedangkan lokko lebih pada perspektif kolektif seperti keluarga besar ataupun marga bahkan masyarakat secara umum. 
Siri' dan Lokko secara umum dapat diartikan sebagai kedudukan atas harga diri yang membentuk emosi (rasa malu) seseorang sehingga melahirkan anggapan/penilaian dari orangorang disekitarnya tentang kedudukan sifat dan prilaku orang tersebut dalam bermasyarakat. Siri dan lokko mengajarkan orang Mandar tentang kedudukan setiap orang pada dasarnya sama, hal yang membuat seseorang jadi berbeda adalah tergantung pada kesadarannya dalam mengamalkan nilai-nilai angga dalam kehidupannya. Pentingnya nilai siri dan lokko dalam kebudayaan masyarakat Mandar menjadikan nilai-nilai ini menjadi muatan pendidikan informal paling awal yang diajarkan pada anak-anak dalam lingkungan keluarga orang-orang Mandar.

\section{b. Stratifikasi kelas sosial}

Dalam sistem sosial budaya Mandar juga dikenal sistem stratifikasi sosial masyarakat berdasarkan kelas-kelas. Mallinckrodt dan Friedricy dalam Rahman (2015: 83-88) mengungkapkan Ada empat kelas sosial yang dijadikan acuan dalam menentukan kedudukan seseorang yakni kelas: 1) Todiang laiyana/maraqdia (kelas bangsawan); 2) Tau pia (orang-orang pilihan); 3) Tau samar'/tau maredeka (orang bebas atau merdeka); dan yang terkahir 4) Batua (budak).

Sebelum terbentuknya kerajaan Balanipa yang banyak mempengaruhi sistem sosial orangorang Balanipa, masyarakat Balanipa tidak mengenal sistem stratifikasi sosial dalam bentuk pemisahan-pemisahan kelas. Semua orang yang hidup pada awalnya adalah orang-orang bebas (tau maradeka). Mereka menempati wilayah-wilayah kecil seperti perkampungan yang disebut ana banua (kampung kecil). Jika terdapat perselisihan maka konsep homo homini lupus (yang kuat memangsa yang lemah) atau hukum rimba berlaku sehingga kekacauan dalam kehidupan masyarakat pada saat itu kerap terjadi. Hal ini dapat ditemukan dalam cerita tentang keberadaan bala tau yang merupakan arena yang terbuat dari batu sebagai pembatasnya. Jika terjadi perselisihan dalam kehidupan sehari-hari dan tidak ditemukan penyelesaian atas perselisihan tersebut maka di bala tau inilah orang-orang yang berselisih tersebut akan saling beradu/berkelahi dan disaksikan oleh masyarakat banyak. Orang yang memenangkan perkelahian sekaligus adalah orang yang memenangkan perselisihan. (Hannan, Muhlis. Personal Communication. 2019. 20 September)

Kekacauan kondisi pada saat itu perlahan-lahan menciptkan kesadaran sendiri dari para anggota masyarakat bahwa diperlukan orang-orang yang bisa dijadikan pendamai, pengambil keputusan sekaligus pengayom masyarakat tanpa harus saling membunuh agar bisa tercipta sistem yang harmonis. Orang yang selanjutnya dipilih inilah yang dikenal dengan istilah tomawuweng (orang tua/yang dituakan). Tomawuweng dalam masyarakat Balanipa menjalankan fungsi semacam hakim arbitrase atau pengadil yang ditunjuk oleh masyarakat yang bertikai. Berdasarkan fungsinya ini pula maka mutlak seorang Tomawuweng adalah orang-orang yang dianggap memiliki pemahaman paling baik terhadap angga dan ada' sebagai dasar untuk menentukan mereka yang bersalah terhadap suatu perselisihan.

Semakin kompleksnya permasalahan yang dihadapi kelompok masyarakat yang hidup di ana banua mendorong mereka untuk mencari dan menemukan lagi seorang pemimpin yang bisa memberikan mereka jaminan atas keamanan, keteraturan dan juga yang bisa mempersatukan terlebih semakin banyaknya ancaman yang muncul dari luar perkampungan. Sosok pemimpin yang diharapkan oleh masyarakat kampung adalah mereka yang memiliki kecerdasan, kekuatan, keberanian bahkan kesaktian agar mampu menjadi penyelamat dan penjaga kehidupan masyarakat ana banua. Pemimpin inilah yang dikenal dengan sebutan Tomakaka (yang 
dituakan/yang memimpin) yang memiliki kedudukan sebagai pemimpin ana yang dipilih oleh masyarakat ana banua dan disetujui oleh para tomawuweng.

Dalam perkembangannya para tomakaka inilah yang dianggap sebagai penguasa-penguasa kecil yang memimpin setiap perkampungan. Pada masa ini pula sistem pemerintahan di ana banua mulai berjalan walupun masih secara tradisionil dengan Tomakaka sebagai pemimpin pemerintahan yang dibantu oleh tomawuweng. Para Tomakaka inilah yang kemudian mendapatkan gelar puang sebagai bentuk penghargaan atas kedudukan dan kekuasaan yang dimilikinya dalam mengatur masyarakat yang bernaung dalam ana banua

Dapat dilihat bahwa bentuk perolehan kekuasaan yang terbentuk dalam kepemimpinan tomakaka didaptkan secara konsensus atau kesepakatan dari masyarakat. Jarang sekali ditemukan dalam catatan sejarah Mandar khususnya pada era sebelum terbentuknya kerajaan Balanipa para tomakaka yang mendapatkan kekuasaan yang berasal dari konflik atau penguasaan secara koersif/kekerasan. Hal tersebut disebabkan karena penguasaan secara kekerasan tentunya tidak sesuai dan bertentangan dengan nilai sosial dan budaya dasar orang Mandar yakni angga, siri' dan lokko yang menentang segala bentuk penindasan dan perlakuan semena-mena terhadap orang lain. (Ilyas, Personal Communication. 2019. 29 September)

Di masa kepemimpinan tomakaka, stratifikasi sosial yang terbentuk hanya kelompok orang kebanyakan atau orang bebas (tau maradeka) dengan orang-orang terpilih/pilihan (tau pia). Tau pia merupakan perwujudan Tomakaka sebagai pemimpin atau pengayom setiap anggota kelompok dari masing-masing perkampungan. Jadi lahirnya kelas-kelas pada awalnya lebih didasari karena diperlukannya sosok pemimpin yang menjadi pengarah dan pelindung kehidupan sehari-hari. Walaupun ada perbedaan antara tau maradeka dengan tau pia namun dalam konteks kemasyarakatan tau maradeka dan tau pia ini tidak pernah terpisah karena tau pia dianggap representasi dari kelompok to maradeka.

Setelah terbentuknya kerajaan Balanipa yang ditandai dengan kedatangan I Manyambungi maka kelas sosial juga bertambah yakni kelas maraqdia. Kelas maraqdia merupakan perwujudan kedudukan sosial dari para raja-raja Balanipa dan turunannya. Walaupun pada awalnya kelas maraqdia ini merupakan gelar yang diberikan dari para tau pia sebagai pemimpin wilayah dan rakyat yang mendelegasikan kekuasaannya kepada maraqdia namun dalam perkembangannya kedua kelas ini ada dalam kedudukan yang sama karena kaum maraqdia ini dianggap memiliki kemampuan dalam memimpin dan mengarahkan masyarakat sedangkan tau pia dianggap kelompok yang memiliki kekuasaan langsung atas wilayah dan rakyat.

Selain golongan tau maradeka, tau pia dan maraqdia, ada juga kelas batua. Kelas batua ini secara terminologis dapat diartikan sebagai kelas budak yang menempati stratifikasi terendah dari kelas sosial yang berlaku pada masyarakat Balanipa. Akan tetapi jika merujuk pada istilah budak yang dipahami oleh masyarakat Balanipa maka pendekatan dan perlakuan yang diberikan pada golongan batua ini jauh berbeda dengan konsep budak yang secara umum biasa dipahami.

Masyarakat Balanipa lebih memaknai budak sebagai orang yang bisa dimintai pertolongan dan bantuan untuk mengurusi berbagai urusan, seperti urusan rumah tangga, berkebun dan semacamnya. keberadaan kaum batua terjadi apabila ada orang ataupun keluarga yang secara langsung menggantungkan hidup dan mendapatkan perlindungan dari golongan tau pia dan maraqdia dalam waktu yang relatif lama yang menyebabkan mereka akan merasa berutang budi. Kaum batua secara sosial tidak serta-merta dapat diperlakukan sewenang-wenang oleh kelas tau pia ataupun maraqdia, mereka tidak boleh dianiaya ataupun disiksa, tidak boleh dipaksa bekerja dan jika mereka menolak untuk mengikuti keinginan kaum tau pia dan maraqdia dengan alasan tertentu maka mereka harus dilindungi. 
Berdasarkan kondisi stratifikasi sosial tersebut dapat terlihat bahwa terjadi bentuk kesetaraan dalam masyarakat Balanipa. Adanya kelas-kelas sosial yang terbentuk lebih karena adanya perbedaan fungsi dan peran tiap-tiap kelompok dalam kehidupan sosial kemasyarakatan dan bukan karena perbedaan hak-hak dasar. Setiap orang yang tinggal dan hidup dalam masyarakat Balanipa memiliki kedudukan yang sama untuk hidup, mendapatkan perlindungan dan tidak diperlakukan sewenang-wenang.

\section{c. Musyawarah dan Gotong royong}

Dalam kalangan masyarakat Mandar, hampir semua urusan-urusan yang berkaitan dengan kepentingan orang banyak ditentukan dan diputuskan solusinya secara bersama-sama. Ini sebagai bentuk keterbukaan dan penghargaan atas kedudukan setiap orang. Setiap anggota masyarakat dianggap memiliki peran dan fungsinya masing-masing dalam sistem kehidupan orang Balanipa. Oleh karena itu dalam pengambilan keputusan selalu dilakukan secara bersama-sama sehingga terbentuk tanggung jawab dari semua anggota masyarakat untuk menjalankan hasil keputusan yang telah disepakati.

Musyawarah dalam kebiasaan orang Mandar dikenal dengan istilah Sirumung Karaya (perkumpulan besar), adapun proses pertukaran pendapat yang terjadi dalam untuk mendapatkan kata sepakat disebut assamaturuang (bersepakat) dan hasil keputusan disebut assamalewuang (hasil keputusan/kesepakatan).

Selain musyawarah, nilai-nilai tradisi terkait kebersamaan juga ditunjukkan dengan kebiasaan sikalulu (saling membantu) yang dimaknai sebagai bentuk kerja sama atau gotong royong. Bentuk sikalulu biasanya sebagai tindak lanjut asssamalewuang (hasil kesepakatan) dari sirumung karayya (musyawarah) terlebih untuk hal-hal yang sifatnya kepentingan umum seperti mengusir pengganggu/penjajah, pembangunan/perbaikan infrastruktur, pelaksanaan upacara adat hari-hari besar keagamaan dan lain sebagainya. Namun adakalanya sikalulu sifatnya insidentil dalam lingkup kepentingan yang lebih personal untuk membantu keperluan/kesusahan orang lain atas dasar saling tolong-menolong seperti memindahkan/mengangkat rumah, membantu di ladang (membersihkan lahan atau panen), mendorong perahu, acara syukuran, khittanan, pernikahan, kecelakaan dan kematian. (Ridwan, Muhammad. Personal Communication. 2019. 24 September)

Adanya bentuk musyawarah dan gotong royong yang hidup dan berkembang di masyarakat Mandar bahkan masih terus terjaga sampai saat ini memeberikan gambaran bahwa sejak awal nilai-nilai kesetaraan dan kebersamaan menjadi landasan pembentuk kebudayaan Mandar. Nilainilai ini tentunya sejalan dengan prinsip demokratisasi yang pada akhirnyamembawa kerajaan Balanipa mencapai masa-masa kejayaannya.

\section{Kesimpulan}

Demokrasi sebagai salah satu bentuk sistem pemerintahan yang paling dominan diterapkan dinegara-negara dunia saat ini dianggap sebagai solusi untuk menciptakan negara kesejahteraan. Walaupun konsep tentang demokrasi itu sendiri menguat dalam satu abad terakhir ini, nyatanya penerapan sistem demokrasi telah banyak diterapkan di Indonesia masa lampau salah satunya adalah di Sulawesi Barat yang dapat dilihat dalam sistem pemerintahan dan sistem sosial Kerajaan Balanipa yang berdiri sejak abad ke XVI.

Nilai-nilai demokrasi yang melekat dalam kehidupan orang Mandar dalam hal ini kerajaan Balanipa mencakup sistem pemerintahan dimana ditemukannya bentuk sistem perwakilan masyaraka dalam kekuasaan yang direpresentasikan oleh Appe Banua Kayyang. Sistem 
kekuasaan yang terbentuk melalui bentuk kompromi yang baik antara perwakilan rakyat dengan raja Balanipa, sistem penentuan kepala pemerintahan dalam hal ini raja yang dipilih secara ketat oleh Appe Banua Kayyang dimana calon-calonnya terbuka untuk semua orang yang memiliki kemampuan dan kompetensi serta tidak adanya sistem pewarisan tahta raja secara turun-temurun.

Selain itu di kerjanaan Balanipa juga menjunjung tinggi pengakuan terhadap hak-hak dasar termasuk didalamnya persamaan hak antara laki-laki maupun perempuan, kedekatan antara raja dan rakyat yang menggambarkan kepedulian raja terhadap kebutuhan rakyat juga tercermin dari simbol-simbol kemasyarakat, sebagai contohnya dapat dilihat dari tidak adanya istana kerajaan yang memungkinkan raja dan rakyat saling terbuka satu sama lain. Selanjutnya adanya bentuk pemisahan kekuasaan antara legislatif, eksekutif dan yudikatif juga menjadi gambaran tingginya penerapan nilai-nilai demokrasi dalam membangun pemerintahan kerajaan Mandar.

Dalam sistem sosial kemasyarakatan, orang Mandar dalam hal ini Kerajaan Balanipa hidup dalam nilai-nilai kebebasan dan saling menghargai satu sama lain. Masyarakat Mandar yang menjadikan nilai/harga diri sebagai puncak dari kemuliaannya dapat dilihat dalam nilai-nilai dasar orang Mandar (angga, siri dan lokko), terbentuknya stratifikasi sosial lebih karena adanya perbedaan peran dan fungsi kelompok-kelompok masyarakat yang dilandasi semangat kemerdekaan dan saling menjaga satu sama lain. Kebebasan untuk berpendapat dan aktif dalam pembangunan terlihat dari budaya sikalulu (gotong-royong) dan sirumung karayya (bermusyawarah).

Kompleksnya nilai-nilai demokratisasi dalam kehidupan masyarakat Mandar dan dalam sistem pemerintaan kerajaan Balanipa seperti yang diungkapkan diatas memberikan kita gambaran bahwa penerapan nilai-nilai demokrasi telah lama diimplementasikan di Sulawesi Barat, nilai-nilai luhur ini jika kita cermati adalah dasar pembentuk peradaban masyarakat Mandar. Hal yang tidak bisa dipungkiri sekaligus menjadi ironi atas nama modernisasi kita justru memunggungi dan nyaris melupakan kearifan luhur ini.

\section{Bibliografi \\ Buku Referensi}

Abdurrahman, Dudung. 1999. Metode Penelitian Sejarah, Jakarta: Logos Wacana Ilmu.

Amir, Muhammad. 2011. Konflik Balanipa-Belanda di Mandar 1862-1872. Makassar: Tesis Magister Universitas Hasanuddin. Tidak dipublikasikan

2014. Gerakan Mara'dia Tokape di Mandar 1870-1873. Makassar: De La Macca, 2014.

Asdy, Ahmad. 2003. Mandar Dalam Kenangan Tentang Latar Belakang Keberadaan Arajang Balanipa Ke-52. Makassar: Yayasan Maha Putra Mandar

Bungin, Burhan. 2001. Metode Penelitian Kualitatif. Aktualisasi Metodologis ke Arah Ragam Varian Kontemporer. Jakarta: Rajawali Press.

Busroh, Abu Daud. 2010. Ilmu Negara. Jakarta: Bumi Aksara. 
Centre for Civic Education. 2007. Elements of Democracy: The Fundamental Principles, Concepts, Social Foundations, and Processes of Democracy. N.p.: CCE.

Friedman, John. 1992. Empowerment: the Politics of Alternative Development. Cambridge \& Oxford: Blackwell.

Leyds, W.J. 2006. Memoar of The Resident Assistant W.J Leyds. Diterjemahkan oleh Hanoch Luhukay \& B.E. Tuwanakota

Saharuddin. 1977. Susunan dan Sistem Pemerintahan Balanipa Dahulu Dalam Hubungannya dengan Kebudayaan Daerah Mandar, dalam Bingkisan Budaya Sulawesi Selatan. Ujung Pandang: Yayasan Kebudayaan Sulawesi Selatan.

1985. Mengenal Pitu Babana Binanga (Mandar) dalam Lintasan Sejarah Pemerintahan Daerah di Sulawesi Selatan. Ujung Pandang: CV. Mallomo Karya.

Polinggomang, Edward L. 2012. Sejarah dan Budaya Sulawesi Barat. Makassar: De La Macca.

Rahman, Darmawan Mas'ud. Puang dan Daeng: Sistem Nilai Budaya Orang Balanipa-Mandar. Makassar: Yayasan Menara Ilmu. 2015

Sjam, A.M. Sarbin, 1990. Struktur Pemerintahan Kerajaan Balanipa dan Fungsi-Fungsi Pejabatnya. Tinambung: Depdikbud.

Trigg, Roger. 2007. Religion in Public Life: Must Faith Be Privatized?. Oxford: Oxford University Press

\section{Jurnal}

Halim, Wahyuddin. 2016. Eksplorasi Atas Praktik Dan Nilai-Nilai Demokrasi Dalam Kerajaan Wajo' Abad Ke-15/16 Dan Kompatibilitasnya Dengan Sistem Demokrasi Modern. Jurnal Masyarakat \& Budaya, Volume 18 No. 2 Tahun 2016.

Kila, Syahrir. 2014. Hubungan Kerajaan Gowa Dengan Kerajaan Balanipa Mandar, dalam Jurnal Walasuji, Volume 5, Nomor 2 Tahun 2014.

Nur Iqmal, 2016. Kerajaan Balanipa pada Abad XVI-XVII Masehi. Jurnal Sejarah dan Kebudayaan Rihlah Vol 4 No. 12016

Sahabuddin, Chuduriah. 2013. Sebuah Sistem Sibaliparri Dalam Keluarga Mandar. Jurnal Papatuzdu, Vol 5 No.1 Tahun 2013.

Thalhah, H.M. 2009. Teori Demokrasi dalam Wacana Ketatanegaraan Perspektif Pemikiran Hans Kelsen. Jurnal Hukum Ius Quia Iustum No. 3 Vol. 16 Juli 2009

Yulistyowati, Efi, dkk. 2016. Penerapan Konsep Trias Politica Dalam Sistem Pemerintahan Republik Indonesia: Studi Komparatif Atas Undang-Undang Dasar Tahun 1945 Sebelum Dan Sesudah Amandemen. Jurnal Dinamika Sosial Budaya, Volume 18, Nomor 2, Desember 2016 
